\title{
PETA SEKTOR EKONOMI PROVINSI KALIMANTAN UTARA
}

\author{
ECONOMIC SECTOR MAP OF NORTH BORNEO PROVINCE
}

\author{
Djuanda Hatta ${ }^{1)}$, Agus Tri Darmawanto ${ }^{2)}$ \\ hattadjuanda@gmail.com ${ }^{1)}$,tridrm7@gmail.com ${ }^{2)}$ \\ Universitas Borneo Tarakan
}

Abstrak: Penelitian ini bertujuan untuk memetakan sektor ekonomi di Provinsi Kalimantan Utara yang dapat menjadi acuan bagi pemerintah dan pihak yang terkait dalam perumusan kebijakan pembangunan ekonomi yang bersifat sektoral. Alat analisis yang digunakan adalah Static Location Quotient (SLQ) dan Dinamic Location Quotien (DLQ) untuk melihat proporsi/kapasitas dan pertumbuhan/perkembangan sektor ekonomi. Tipologi Klassen digunakan untuk memetakan sektor ekonomi tersebut. Hasil analisis menunjukkan empat kuadran peta ekonomi yaitu kuadran pertama yang merupakan sektor yang maju dan tumbuh dengan cepat terdiri atas: Pertanian, Kehutanan, dan Perikanan; Pertambangan dan Penggalian; Konstruksi; Administrasi Pemerintahan, Pertahanan dan Jaminan Sosial Wajib, kuadran kedua yang merupakan sektor yang maju tapi tertekan terdiri atas: Transportasi dan Pergudangan, Kuadran ketiga yang merupakan sektor yang berkembang cepagt terdiri atas: Pengadaan Listrik dan Gas; Perdagangan Besar dan Eceran; Reparasi Mobil dan Sepeda Motor; Penyediaan Akomodasi dan Makan Minum; Real Estate; Jasa Pendidikan; Jasa Kesehatan dan Kegiatan Sosial; Jasa Lainnya, Kuadran keempat yang merupakan sektor yang relatif tertinggal terdiri atas: Industri Pengolahan; Pengadaan Air, Pengelolaan Sampah, Limbah dan Daur Ulang; Informasi dan Komunikasi; Jasa Keuangan; Jasa Perusahaan.

Kata kunci: Static Location Quotient (SLQ), Dinamic Location Quotient (DLQ), Tipologi Klassen, Peta Sektor Ekonomi

Abstract: This study aimed to map the economic sector in the North Borneo Province which can be a reference for the government and related parties in the formulation of sectoral economic development policies. The analytical tools used were Static Location Quotient (SLQ) and Dynamic Location Quotient (DLQ) to see the proportion/capacity and growth/development of the economic sector. Klassen's typology was used to map the economic sector. The results of the analysis showed four quadrants of the economic map: the first quadrant which is a developed and fast growing sector consisting of: Agriculture, Forestry, and Fisheries; Mining and excavation; Construction; Government Administration, Defense and Compulsory Social Security, the second quadrant which is a developed but distressed sector consisting of: Transportation and Warehousing, the third quadrant which is a rapidly developing sector consisting of: Procurement of Electricity and Gas; Wholesale and retail trade; Car and Motorcycle Repair; Provision of Accommodation and Food and Drink; Real estate; Educational Services; Health Services and Social Activities; Other 
Services, The fourth quadrant which is a relatively lagging sector consists of: Manufacturing Industry; Water Supply, Waste Management, Waste and Recycling; Information and Communication; Financial Services; Company Services.

Keywords: Static Location Quotient (SLQ), Dynamic Location Quotient (DLQ), Klassen Typology, Economic Sector Map

\section{PENDAHULUAN}

Pembangunan perekonomian merupakan salah satu indikasi perkembangan suatu wilayah dalam mencapai kemajuan serta tingkat kesejahteraan yang diinginkan. Namun pada kenyataannya, pembangunan ekonomi baik dalam konteks negara maupun daerah sering tidak merata sehingga dapat menimbulkan ketimpangan pembangunan baik antarkabupaten/kota, antardaerah, maupun antar sektor ekonomi.

Pembangunan ekonomi merupakan bagian dari pembangunan nasional, pada awalnya hanya berorientasi pada masalah pertumbuhan semata. tujuan utama pembangunan ekonomi selain untuk menciptakan pertumbuhan yang setinggi-tingginya, harus pula berupaya untuk menghapus atau mengurangi tingkat kemiskinan, ketimpangan pendapatan dan tingkat pengangguran atau upaya menciptakan kesempatan kerja bagi penduduk. karena dengan kesempatan kerja, masyarakat akan memperoleh pendapatan untuk memenuhi kebutuhan hidupnya (Todaro \& Smith, 2011).

Untuk melaksanakan pembangunan dengan sumber daya yang terbatas sebagai konsekuensinya harus difokuskan kepada pembangunan sektor- sektor yang memberikan dampak pengganda (multiplier effects) yang besar terhadap sektor-sektor lainnya atau perekonomian secara keseluruhan (Kurniawan, 2016).

Pembangunan ekonomi daerah adalah suatu proses di mana pemerintah daerah dan masyarakat mengelola sumber daya yang ada dan membentuk suatu pola kemitraan antara pemerintah dan sektor swasta untuk menciptakan lapangan kerja atau kesempatan kerja baru dan merangsang pertumbuhan ekonomi. karena kesempatan kerja merupakan peluang bagi penduduk untuk melaksanakan fungsinya sebagai sumber daya ekonomi dalam proses produksi untuk memperoleh pendapatan.

Berdasarkan data badan pusat statistik pertumbuhan ekonomi di Provinsi kalimantan Utara dan indonesia 2014-2017 adalah:

Tabel 1 : perbandingan Pertumbuhan ekonomi Kalimantan Utara dan Indonesia (\%)

\begin{tabular}{lrrrrrr}
\hline & 2014 & 2015 & 2016 & 2017 & 2018 & 2019 \\
\hline Kalimantan Utara & 8.18 & 3.4 & 3.75 & 6.59 & 6.44 & 7.31 \\
Indonesia & 5.01 & 4.88 & 5.03 & 5.07 & 5.17 & 5.02 \\
\hline
\end{tabular}

Sumber: BPS Provinsi Kalimantan Utara tahun 2019, diolah 
Sedangkan data pendapatan dan Indonesia (ribu rupiah) 2014perkapita Provinsi Kalimantan Utara 2017 adalah:

Tabel 2 : perbandingan pendapatan perkapita Kalimantan Utara dan Indonesia (ribu rupiah)

\begin{tabular}{lrrrrrr}
\hline & 2014 & 2015 & 2016 & 2017 & 2018 & 2019 \\
\hline Kalimantan Utara & $77,152.60$ & $76,823.46$ & $76,785.54$ & $78,914.52$ & $80,716.46$ & NA \\
Indonesia & $37,110.38$ & $38,138.93$ & $39,255.09$ & $47,966.58$ & NA & NA \\
\hline
\end{tabular}

Sumber: BPS Provinsi Kalimantan Utara tahun 2019, diolah

Berdasarkan data tersebut menunjukkan bahwa provinsi Kalimantan Utara merupakan daerah yang pertumbuhan ekonominya lebih tinggi daripada pertumbuhan ekonomi nasional dan pendapatan perkapitanya lebih tinggi daripada pendapatan perkapita nasional. Typologi Klansen menyatakan bahwa wilayah yang memenuhi syarat tersebut merupakan daerah yang maju dan tumbuh cepat.

Permasalah ketimpangan masih menjadi momok sehingga diperlukannya pembangunan ekonomi di berbagai sektor. Selama revolusi industri, disparitas income perkapita telah meningkat secara dramatis, standar deviasi log output per tenaga kerja meningkat dari 0,42 pada tahun 1820 menjadi 1.12 tahun 2010 (Tamura, Dwyer, Devereux, \& Baier, 2019). Demikian halnya era industri 4.0 akan semakin memungkinkan terjadin ya disparitas pendapatan yang semakin tajam.

Menindak lanjuti hal tersebut, lebih lanjut perlu dilakukan pendekatan sektoral untuk menitik beratkan perhatian pemerintah, ekonom dan pihak terkait. Berdasarkan data Badan Pusat Statistik Provinsi Kalimantan Utara, data Produk Domestik Regional Bruto (PDRB) dan Kontribusi masing-masing sektor ekonomi adalah sebegai berikut :

Tabel 3 : PDRB dan Kontribusi Sektor Ekonomi Provinsi Kalimantan

Utara tahun 2019

\begin{tabular}{lrr}
\hline Kategori/Lapangan Usaha & \multicolumn{1}{c}{$\begin{array}{c}\text { Nilai } \\
\text { (juta rupiah) }\end{array}$} & $\begin{array}{c}\text { Kontribusi } \\
\text { (persen) }\end{array}$ \\
\hline A. Pertanian, Kehutanan, dan Perikanan & $15,473,520.10$ & 15.88 \\
B. Pertambangan dan Penggalian & $26,259,903.00$ & 26.94 \\
C. Industri Pengolahan & $8,961,292.20$ & 9.19 \\
D. Pengadaan Listrik dan Gas & $50,798.70$ & 0.05 \\
E. Pengadaan Air, Pengelolaan Sampah, Limbah dan Daur Ulang & $56,738.90$ & 0.06 \\
F. Konstruksi & $13,389,502.60$ & 13.74 \\
G. Perdagangan Besar dan Eceran; Reparasi Mobil dan Sepeda Motor & $11,698,244.60$ & 12.00 \\
H. Transportasi dan Pergudangan & $6,871,591.30$ & 7.05 \\
I. Penyediaan Akomodasi dan Makan Minum & $1,574,480.60$ & 1.62 \\
J. Informasi dan Komunikasi & $2,262,828.70$ & 2.32 \\
K. Jasa Keuangan & $1,065,036.30$ & 1.09 \\
L. Real Estate & $746,027.40$ & 0.77 \\
M,N. Jasa Perusahaan & $213,950.30$ & 0.22 \\
O. Administrasi Pemerintahan, Pertahanan dan Jaminan Sosial Wajib & $4,828,881.50$ & 4.95 \\
P. Jasa Pendidikan & $2,380,293.30$ & 2.44 \\
\hline
\end{tabular}


Q. Jasa Kesehatan dan Kegiatan Sosial

$988,706.70$

1.01

R,S,T,U. Jasa Lainnya

$636,608.90$

0.65

Sumber : BPS Provinsi Kalimantan Utara tahun 2020, diolah

Data tersebut menunjukkan bahwa tiga sektor yang paling berkontribusi besar terhadap total PDRB adalah sektor Pertambangan dan Penggalian sebesar 26,94 \%, sektor pertanian, Kehutanan dan Perikanan sebesar $15,88 \quad \%$ dan sektor Konstruksi sebesar 13,74\%. Secara kontribusi, sektor-sektor ini bisa menjadi penggerak perekonomian sehingga mendukung sektor-sektor ekonomi lainnya yang berpotensi untuk berkembang di provinsi Kalimantan Utara. Akan tetapi perlu dilakukan pemetaan sektor sehingga nampak keunggulan dan kelemahan masing-masing sektor baik dari segi kontribusi dan pertumbuhannya.

Dalam penyusunan dokumen perencanaan pembangunan daerah yang biasanya dituangkan dalam bentuk RPJMP, PRJMD, RKPD, Restra dalan lain-lain, seringkali tidak diawali dengan studi untuk memetakan sektor basis/sektor unggulan (Ragiliawan, Saputri, \& Nuraeni, 2018). Pemetaan sektor ekonomi merupakan acuan pemerintah, ekonomi, dan pihak terkait dalam upaya perumusan kebijakan terkait pembangunan yang bersifat sektoral. Setiap wilayah mempunyai keunggulan sumberdaya yang perlu dimanfaatkan dan memberikan pendapatan masyarakat. Ketika sektor ekonomi kecil kontribusinya terhadap perekonomian, maka pemerintah dan pihak terkait bisa memberikan dukungan berupa fasilitas dan kemudahan agar sektor tersebut bisa berkontribusi. Ketika sektor ekonomi pertumbuhannya rendah maka berkat dukungan pemerintah pada sektor ini bisa lebih memacu pertumbuhannya.

Sehingga berdasarkan uraian yang telah dikemukakan di atas, maka penulis mencoba untuk membahas lebih lanjut mengenai perlu adanya evaluasi dalam gambaran peta sektor ekonomi provinsi Kalimantan Utara sebagai kerangka acuan kebijakan pemerintah di bidangan ekonomi dengan pendekatan sektoral.

\section{LANDASAN TEORI}

\section{Teori Pembangunan Ekonomi}

Pembangunan ekonomi daerah adalah suatu proses dimana pemerintah daerah dan masyarakat mengelola sumber daya yang ada dan membentuk suatu pola kemitraan antara pemerintah dan sektor swasta untuk menciptakan lapangan kerja atau kesempatan kerja baru dan merangsang pertumbuhan ekonomi (Way, Engka, \& Siwu, 2019)

Sektor swasta mempunyai peranan yang begitu besar terhadap perekonomian. Dengan dukungan sektor swasta kapasitas ekonomi dapat meningkat seiring peningkatan aktivitas produksi, oleh sebab itu diperlukan sinergitas antar pemerintah dan dunia usaha dalam membangun sektor-soktoe ekonomi yang ada di daerah untuk menjamin keberlanjutan pembangunan ekonomi daerah.

Ketika kita mengupayakan pembangunan ekonomi atau 
industrialisasi pada sebuah negara, tidak cukup melihat pada kondisi ekonomi domestiknya, Peforma ekonomi pada wilayah lain lain juga penting (Yanagawa, 1996). Landasan inilah yang mendukung petingnya tiap-tiap daerah memiliki keunggulan komparatif dalam hal pengembangan potensi dengan dukungan sumberdaya yang ada di daerah. Tiap-tiap daerah memiliki corak ekonomi yang berbeda-beda tergantung sumber daya yang dimiliki.

\section{Sektor Unggulan}

Sektor unggulan adalah sektor yang keberadaannya pada saat ini telah berperan besar pada perkembangan perekonomian suatu wialayah, karena mempunyai keuanggulan- keuanggulan/criteria. (Way et al., 2019). Dengan adanya sektor unggulan tersebut dapat menjadi keunggulan komparatif daerah dimana produk unggul nantinya bisa mempunyai daya saing di daerah lain setelah memenuhi kebutuhan domestiknya.

Pemerintah daerah mempunyai tujuan pembangunan yang selalu di titik beratkan pada aspek ekonomi. Dalam upaya mencapai tujuan pembangunan ekonomi daerah, kebijakan utama yang perlu dilakukan adalah mengusahakan semaksimal mungkin agar prioritas pembangunan daerah sesuai dengan potensi yang dimiliki oleh daerah.(Ragiliawan et al., 2018).

\section{Teori Basis Ekonomi}

Upaya pengembangan wilayah sebaiknya memerhatikan potensi unggulan tiap daerah yang ada di kawasan (Kamaruddin \& Alam, 2018). Sebagaimana dibahasakan sebelumnya potensi tersebut dimiliki karena adanya cirikhas sumberdaya yang ada didaerah. Berdasarkan lapangan usaha di PDRB, kita bisa melihat sektor yang besar kontribusinya pada perekonomian, yaitu sektor yang memiliki nilai serta pertumbuhan yang besar.

\section{Teori Location Quotion (LQ)}

Dalam pembangunan ekonomi daerah analisis LQ dapat memberikan gambaran ekonomi daerah berupa sektor unggulan yang dimiliki oleh daerah tersebut (Arsyad, 2005). Sektor unggulan dapat menjadi andalan bagi daerah untuk dijadikan mnotor penggerak perekonomian di samping memberikan kontribusi yang besar terhadap perekonomian.

Berbagai pendekatan dan alat analisis telah banyak digunakan untuk mengidentifikasi komoditas unggulan, menggunakan beberapa kriteria teknis dan non teknis dalam kerangka memenuhi aspek penawaran dan permintaan (Hendayana, 2016). Analisis LQ mengukur konsentrasi dari suatu Sektor ekonomi dalam suatu daerah dengan cara membandingkan peranannya dalam perekonomian daerahtersebut dengan peranan kegiatan ekonomi sejenis pada lingkup yang lebih luas baik itu provinsi atau nasional (Kamaruddin \& Alam, 2018).

\section{Teori Tipologi Klassen}

Tipologi Klassen merupakan salah satu alat analisis ekonomi regional yang dapat digunakan untuk 
mengetahui klasifikasi sektor perekonomian wilayah. Analisis tipologi klassen digunakan dengan tujuan mengetahui klasifikasi sektor berdasarkan dua indikator utama, yaitu laju pertumbuhan ekonomi dan kontribusi Produk Domestik Regional Bruto (PDRB) dengan melihat posisi perekonomian suatu daerah dan memperhatikan perekonomian daerah referensi (Kamaruddin \& Alam, 2018).

Kemajuan dan pertumbuhan ekonomi setiap wilayah tentunya masing-masing berbeda. Ada wilayah yang mampu memacu kegiatan ekonominya sehingga dapat tumbuh pesat. Di sisi lain ada pula wilayah yang tak dapat berbuat banyak sehingga siklus ekonominya stagnan di satu titik atau bahkan tumbuh negatif (Kamaruddin \& Alam, 2018).

Analisis Tipologi Klassen dapat digunakan dengan tujuan mengidentifikasi posisi sektor perekonomian suatu daerah misalnya kabupaten, dengan memperhatikan sektor perekonomian di daerah yang lebih luas sebagai daerah referensi, misalnya propinsi atu nasional (Ragiliawan et al., 2018).

Implementasi Tipologi

Klansen bisa juga dilakukan dalam berbagai aspek, misalnya sektor ekonomi/lapangan usaha, tenaga kerja, produk unggulan hingga sektor moneter. Dengan pemetaan ini bisa mengukur kapasitas sektor dibandingkan dengan wilayah lainnya berdasarkan sektor yang sama pada skala yang lebih luas.

\section{METODOLOGI PENELITIAN}

\section{Variabel Penelitian}

Variabel penelitian adalah PDRB Provinsi Kalimantan Utara berdasarkan lapangan usaha atas dasar harga berlaku dan atas dasar harga konstan tahun tahun 20142018 yang diperoleh dari Badan Pusat Statistik (BPS) Provinsi Kalimantan Utara dan PDB Indonesia berdasarkan lapangan usaha atas dasar harga berlaku dan atas dasar harga konstan tahun 20142018 yang diperoleh dari BPS Indonesia.

\section{Pengumpulan data}

Metode pengumpulan data yang digunakan dalam penelitian ini adalah metode kepustakaan dengan mengumpulkan data-data dan informasi yang berasal dari publikasi ilmiah seperti: jurnal, laporan penelitian, dan literarur-literatur yang terkait dengan penelitian ini. Data yang digunakan adalah data sekunder, yaitu data Produk Domestik Regional Bruto (PDRB) Provinsi Kalimantan Utara atas dasar harga berlaku dan konstan, menurut lapangan usaha tahun 2014- 2018 dan Produk Domestik Bruto (PDB) Indonesia atas dasar harga berlaku dan atas dasar harga konstan menurut lapangan usaha tahun 2014-2018, yang bersumber dari Badan Pusat Statistik (BPS) Provinsi Kalimantan utara dan Indonesia.

\section{Analisis Data}

Penelitian ini menggunakan model analisis analisis Location Quotient (LQ) dan Tipologi Klassen. LQ terbagi atas dua model yaitu Static Location Quotient (SLQ) dan 
Dinamic Location Quotient (DLQ) (Basuki \& Nugroho Mujiraharjo, 2017).

\section{SLQ}

Model SLQ untuk mengetahui perbandingan antara proporsi tiap-tiap sektor ekonomi di provinsi terhadap proporsi sektor ekonomi yang sama di tingkat nasional,

Adapun rumus SLQ tersebut adalah :

$\mathrm{SLQ}=\frac{V i / V t}{Y i / Y t}$

Sumber : Basuki \& Nugroho Mujiraharjo, 2017

Keterangan :

SLQ : besarnya indeks suatu sektor ekonomi

vi : nilai PDRB sektor i di

Provinsi Kalimantan Utara

vt : nilai total PDRB di Provinsi

Kalimantan Utara

yi : nilai PDRB sektor i di Indonesia

yt : nilai total PDRB di Indonesia

Kriteria keputusan dari hasil perhitungan SLQ adalah :

a. Apabila nilai SLQ > 1 , menunjukkan bahwa sektor tersebut mempunyai kontribusi lebih besar dari rata kontribusi sektor tersebut scera nasional

b. Apabila nilai SLQ $<1$, menunjukkan bahwa sektor sektor tersebut mempunyai kontribusi lebih kecil dari rata kontribusi sektor tersebut scera nasional
2. DLQ

Model DLQ untuk mengetahui perbandingan pertumbuhan tiap-tip sektor ekonomi di tingkat provinsi dibandingkan dengan pertumbuhan sektor-sektor ekonomi yang sama di tingkat nasionanl.

$\mathrm{DLQ}=\left[\frac{(1+\boldsymbol{g} \boldsymbol{i} \boldsymbol{j}) /(\mathbf{1}+\boldsymbol{g} \boldsymbol{j})}{(\mathbf{1}+\boldsymbol{G} \boldsymbol{i}) /(1+\boldsymbol{G})}\right]^{t}$

Sumber : Basuki \& Nugroho Mujiraharjo, 2017

Keterangan :

DLQ : Dinamika/proyeksi sektor perekonomian

gij : Laju pertumbuhan PDRB sektor i di Provinsi Kalimantan Utara gj : Rata-rata laju pertumbuhan PDRB sektor di Provinsi Kaliamntan Utara

Gi : Laju pertumbuhan PDB sektor i di Indonesia

G : Rata-rata laju pertumbuhan PDB sektor di Indonesia

t : Selisih tahun akhir dan tahun awal (2015-2018)

Keputusan dari hasil perhitungan DLQ adalah:

a. hasil DLQ $>1$, menunjukkan bahwa pertumbuhan sektor tersebut di Provinsi Kalimantan Utara lebih cepat/diatas rata-rata pertumbuhan sektor tersebut secara nasional.

b. nilai DLQ < 1, menunjukkan bahwa pertumbuhan sektor tersebut di Provinsi Kalimantan Utara lebih lambat/dibawah ratarata pertumbuhan sektor tersebut secara nasional. 


\section{Typologi Klassen}

Model Analisis Tipologi Klassen digunakan untuk mengetahui gambaran tentang peta dan struktur sektor ekonomi di Kalimantan Utara. Tipologi klassen pada dasarnya membagi wilayah berdasarkan dua indikator utama, yaitu proporsi sektor ekonomi dan pertumbuhan seektor ekonomi.

Tipologi klassen memetakan sektorsektor ekonomi menjadi empat kuadran, dimana:

a. kuadran pertama (SLQ $>1$ dan DLQ $>1)$ merupakan sektor yang maju dan tumbuh dengan cepat, b. kuadran kedua (SLQ $>1$ dan $\mathrm{DLQ}<1)$ merupakan sektor yang maju tapi tertekan,

c. kuadran ketiga (SLQ $<1$ dan DLQ $>1$ ) merupakan sektor yang berkembang, dan

d. kuadran keempat ( $\mathrm{SLQ}<1$ dan DLQ $<1)$ merupakan sektor yang relatif tertinggal.

\section{HASIL DAN PEMBAHASAN}

Hasil analisis SLQ dan DLQ dapat di tujukkan pada tabel berikut :

Tabel 4 : hasil analisis SLQ tahun 2014-2018

\begin{tabular}{|c|c|c|c|c|c|c|c|}
\hline \multirow[t]{2}{*}{ Kategori/Lapangan Usaha } & \multicolumn{7}{|c|}{$(\mathrm{ViP} / \mathrm{VP}) /(\mathrm{ViN} / \mathrm{VN})$} \\
\hline & 2014 & 2015 & 2016 & 2017 & 2018 & 2019 & Rerata \\
\hline A. Pertanian, Kehutanan, dan Perikanan & 1.25 & 1.23 & 1.25 & 1.19 & 1.20 & 1.20 & 1.22 \\
\hline B. Pertambangan dan Penggalian & 3.18 & 3.57 & 3.33 & 3.47 & 3.27 & 3.56 & 3.40 \\
\hline C. Industri Pengolahan & 0.44 & 0.46 & 0.48 & 0.48 & 0.46 & 0.45 & 0.46 \\
\hline D. Pengadaan Listrik dan Gas & 0.03 & 0.04 & 0.04 & 0.04 & 0.04 & 0.04 & 0.04 \\
\hline E. Pengadaan Air, Pengelolaan Sampah, Limbah dan Daur Ulang & 0.80 & 0.80 & 0.84 & 0.87 & 0.88 & 0.82 & 0.84 \\
\hline F. Konstruksi & 1.15 & 1.13 & 1.19 & 1.15 & 1.18 & 1.23 & 1.17 \\
\hline G. Perdagangan Besar dan Eceran; Reparasi Mobil dan Sepeda Motor & 0.72 & 0.78 & 0.85 & 0.84 & 0.86 & 0.88 & 0.82 \\
\hline H. Transportasi dan Pergudangan & 1.27 & 1.26 & 1.27 & 1.24 & 1.27 & 1.21 & 1.25 \\
\hline I. Penyediaan Akomodasi dan Makan Minum & 0.43 & 0.48 & 0.51 & 0.53 & 0.56 & 0.56 & 0.51 \\
\hline J. Informasi dan Komunikasi & 0.57 & 0.61 & 0.61 & 0.58 & 0.59 & 0.56 & 0.59 \\
\hline K. Jasa Keuangan & 0.28 & 0.29 & 0.29 & 0.26 & 0.26 & 0.25 & 0.27 \\
\hline L. Real Estate & 0.29 & 0.29 & 0.29 & 0.27 & 0.27 & 0.26 & 0.28 \\
\hline M,N. Jasa Perusahaan & 0.18 & 0.17 & 0.15 & 0.13 & 0.13 & 0.11 & 0.14 \\
\hline O. Administrasi Pemerintahan, Pertahanan dan Jaminan Sosial Wajib & 1.24 & 1.32 & 1.40 & 1.37 & 1.32 & 1.31 & 1.33 \\
\hline P. Jasa Pendidikan & 0.64 & 0.70 & 0.74 & 0.73 & 0.72 & 0.71 & 0.71 \\
\hline Q. Jasa Kesehatan dan Kegiatan Sosial & 0.73 & 0.88 & 0.99 & 0.93 & 0.90 & 0.88 & 0.89 \\
\hline R,S,T,U. Jasa Lainnya & 0.30 & 0.34 & 0.38 & 0.36 & 0.34 & 0.32 & 0.34 \\
\hline PRODUK DOMESTIK REGIONAL BRUTO & 1.00 & 1.00 & 1.00 & 1.00 & 1.00 & 1.00 & 1.00 \\
\hline
\end{tabular}

Sumber : hasil analisis data

Berdasarkan hasil analisis SLQ diketahui bahwa proporsi sektor ekonomi provinsi terhadap PDRB Kalimantan Utara yang lebih besar daripada proporsi sektor ekonomi yang sama pada tingkat nasional terhadap PDB Indonesia (SLQ > 1) adalah: 
1. pertambangan dan galian, sebesar 3,34 ;

2. Administrasi Pemerintahan, Pertahanan dan Jaminan Sosial Wajib, sebesar 1,33;

3. transportasi dan pergudangan, sebesar 1,25;

4. pertanian, kehutanan dan perikanan, sebesar 1,22 ;

5. kontruksi, sebesar 1,17.

Sedangkan proporsi sektor ekonomi provinsi terhadap PDRB Kalimantan Utara yang lebih kecil daripada proporsi sektor ekonomi yang sama pada tingkat nasional terhadap PDB Indonesia (SLQ < 1) adalah:

1. Industri Pengolahan, sebesar 0,46
2. Pengadaan Listrik dan Gas, sebesar 0,04;

3. Pengadaan Air, Pengelolaan Sampah, Limbah dan Daur Ulang, sebesar 0,84;

4. Perdagangan Besar dan Eceran; Reparasi Mobil dan Sepeda Motor, sebesar 0,82;

5. Penyediaan Akomodasi dan Makan Minum, sebesar 0,51;

6. Informasi dan Komunikasi, sebesar 0,59;

7. Jasa Keuangan, sebesar 0,27;

8. Real Estate, sebesar 0,28;

9. Jasa Perusahaan, sebesar 0,14 ;

10. Jasa Pendidikan, sebesar 0,71 ;

11. Jasa Kesehatan dan Kegiatan Sosial, sebesar 0,89;

12. Jasa Lainnya, sebesar 0,34

Tabel 5: hasil analisis DLQ tahun 2015-2018

\begin{tabular}{lcccccc}
\hline Kategori/Lapangan Usaha & \multicolumn{7}{l}{$\left(((1+\mathrm{gij}) /(1+\mathrm{gj})) /((1+\mathrm{Gij}) /(1+\mathrm{Gj}))^{\wedge} \mathrm{t}\right.$} \\
\cline { 2 - 6 } & 2015 & 2016 & 2017 & 2018 & 2019 & Rerata \\
\hline A. Pertanian, Kehutanan, dan Perikanan & 1.00 & 1.01 & 0.99 & 1.01 & 1.02 & 1.01 \\
B. Pertambangan dan Penggalian & 0.98 & 0.95 & 1.05 & 1.01 & 1.03 & 1.01 \\
C. Industri Pengolahan & 0.99 & 1.01 & 0.99 & 0.96 & 1.00 & 0.99 \\
D. Pengadaan Listrik dan Gas & 1.23 & 1.02 & 1.05 & 1.04 & 1.01 & 1.07 \\
E. Pengadaan Air, Pengelolaan Sampah, Limbah dan Daur Ulang & 0.93 & 1.02 & 1.01 & 1.00 & 0.96 & 0.98 \\
F. Konstruksi & 0.95 & 1.02 & 0.98 & 1.00 & 1.05 & 1.01 \\
G. Perdagangan Besar dan Eceran; Reparasi Mobil dan Sepeda Motor & 0.98 & 1.02 & 1.02 & 1.02 & 1.04 & 1.02 \\
H. Transportasi dan Pergudangan & 0.99 & 0.98 & 1.00 & 1.00 & 1.00 & 0.99 \\
I. Penyediaan Akomodasi dan Makan Minum & 1.00 & 1.02 & 1.05 & 1.05 & 1.01 & 1.03 \\
J. Informasi dan Komunikasi & 1.01 & 0.99 & 0.98 & 1.01 & 0.98 & 0.99 \\
K. Jasa Keuangan & 0.97 & 0.96 & 0.97 & 1.03 & 0.98 & 0.98 \\
L. Real Estate & 1.06 & 1.02 & 1.06 & 1.08 & 1.06 & 1.06 \\
M,N. Jasa Perusahaan & 0.89 & 0.89 & 0.94 & 0.94 & 0.92 & 0.92 \\
O. Administrasi Pemerintahan, Pertahanan dan Jaminan Sosial Wajib & 0.99 & 1.04 & 1.03 & 0.98 & 1.01 & 1.01 \\
P. Jasa Pendidikan & 1.00 & 1.02 & 1.02 & 0.99 & 1.03 & 1.01 \\
Q. Jasa Kesehatan dan Kegiatan Sosial & 1.08 & 1.07 & 0.98 & 0.97 & 1.00 & 1.02 \\
R,S,T,U. Jasa Lainnya & 1.05 & 1.03 & 0.97 & 0.97 & 0.98 & 1.01 \\
\hline PRODUK DOMESTIK REGIONAL BRUTO & 1.00 & 1.00 & 1.00 & 1.00 & 1.00 & 1.00 \\
\hline
\end{tabular}

Sumber : hasil analisis data 
Berdasarkan hasil analisis DLQ, pertumbuhan sektor ekonomi provinsi yang lebih tinggi daripada pertumbuhan sektor ekonomi yang sama pada tingkat nasional (DLQ > 1) adalah :

1. Pertanian, Kehutanan, dan Perikanan, sebesar 1,01;

2. Pertambangan dan Penggalian, sebesar 1.01;

3. Pengadaan Listrik dan Gas, sebesar 1,07;

4. Konstruksi, sebesar 1,01;

5. Perdagangan Besar dan Eceran; Reparasi Mobil dan Sepeda Motor, sebesar 1,02;

6. Penyediaan Akomodasi dan Makan Minum, sebesar 1,03;

7. Real Estate, sebesar 1,06;

8. Administrasi Pemerintahan, Pertahanan dan Jaminan Sosial Wajib, sebesar 1,01;
9. Jasa Pendidikan, sebesar 1,01 ;

10. Jasa Kesehatan dan Kegiatan Sosial, sebesar 1,02;

11. Jasa lainnya, sebesar 1,01;

Sedangkan pertumbuhan sektor ekonomi provinsi yang lebih rendah daripada pertumbuhan sektor ekonomi yang sama pada tingkat nasional $(\mathrm{DLQ}<1)$ adalah :

1. Industri Pengolahan, sebesar 0,99 ;

2. Pengadaan Air, Pengelolaan Sampah, Limbah dan Daur Ulang, sebesar 0,99;

3. Transportasi dan Pergudangan, sebesar 0,99;

4. Informasi dan Komunikasi, sebesar 0,99;

5. Jasa Keuangan, sebesar 0,98;

6. Jasa Perusahaan, sebesar 0,91 ;

Tabel 6: kesimpulan hasil analisis SLQ dan DLQ

\begin{tabular}{lcc}
\hline Kategori/Lapangan Usaha & SLQ & DLQ \\
\hline A. Pertanian, Kehutanan, dan Perikanan & 1.22 & 1.01 \\
B. Pertambangan dan Penggalian & 3.40 & 1.01 \\
C. Industri Pengolahan & 0.46 & 0.99 \\
D. Pengadaan Listrik dan Gas & 0.04 & 1.07 \\
E. Pengadaan Air, Pengelolaan Sampah, Limbah dan Daur Ulang & 0.84 & 0.98 \\
F. Konstruksi & 1.17 & 1.01 \\
G. Perdagangan Besar dan Eceran; Reparasi Mobil dan Sepeda Motor & 0.82 & 1.02 \\
H. Transportasi dan Pergudangan & 1.25 & 0.99 \\
I. Penyediaan Akomodasi dan Makan Minum & 0.51 & 1.03 \\
J. Informasi dan Komunikasi & 0.59 & 0.99 \\
K. Jasa Keuangan & 0.27 & 0.98 \\
L. Real Estate & 0.28 & 1.06 \\
M,N. Jasa Perusahaan & 0.14 & 0.92 \\
O. Administrasi Pemerintahan, Pertahanan dan Jaminan Sosial Wajib & 1.33 & 1.01 \\
P. Jasa Pendidikan & 0.71 & 1.01 \\
Q. Jasa Kesehatan dan Kegiatan Sosial & 0.89 & 1.02 \\
R,S,T,U. Jasa Lainnya & 0.34 & 1.01 \\
\hline PRODUK DOMESTIK REGIONAL BRUTO & 1.00 & 1.00
\end{tabular}

Sumber : hasil analisis data 
Dari hasil analisis SLQ dan DLQ di atas maka dapat diklasifikasikan dal bentuk peta sektor ekonomi berdasarkan nalisis Tipologi Klassen sebagai berikut :

Tabel 7 : Peta Sektor Ekonomi berdasarkan Tipologi Klansen

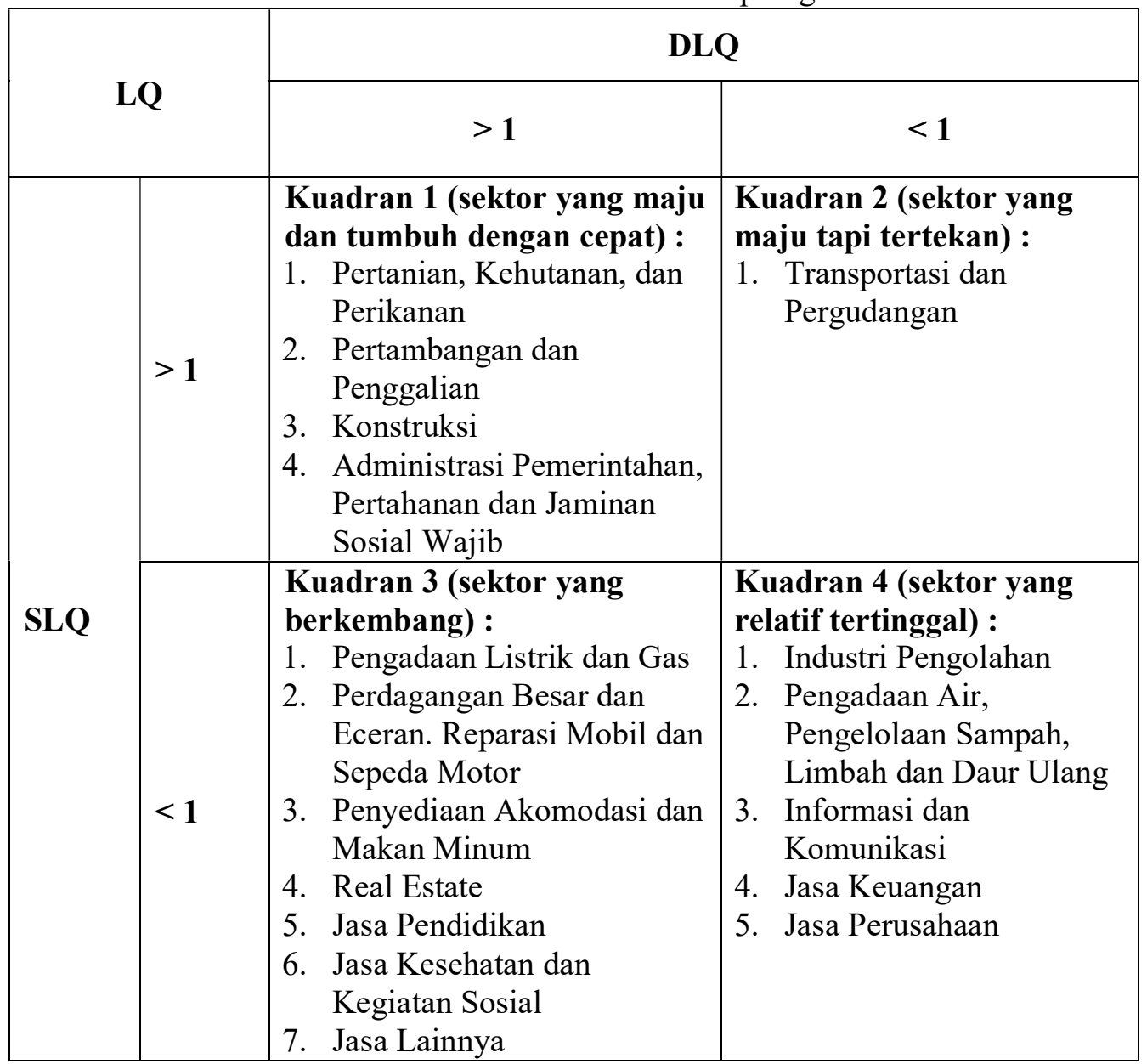

Sumber : hasil analisis data

Berdasarkan pemetaan pada tabel di atas, dapat dilihat bahwa Sektor Pertanian, Kehutanan, dan Perikanan; Pertambangan dan Galian; Konstruksi; dan sektor Administrasi Pemerintahan, Pertahanan dan Jaminan Sosial Wajib merupakan sektor unggulan di Provinsi Kalimantan Utara, dengan angka SLQ dan DLQ yang lebih besar dari satu. Sektor tersebut berkontribusi lebih besar dibandingkan dengan kontribusi sektor yang sama di tingkat nasional. Di samping itu, pertumbuhan sektor tersebut lebih cepat dari pada pertumbuhan sektor yang sama di tingkat nasional.

Corak ekonomi Provinsi Kalimantan Utara adalah ekonomi yang berbasis Agrikultur. Hal ini merupakan petanda bahwa wilayah 
ini masih menyimpan kekayaan sumber daya alam yang melimpah berupa kekayaan alam baik di darat maupun di laut. Dikatakan juga sektor tersebut adalah sektor yang potensial karena kontribusi pendapatan masih bertumbuh, artinya masih menjanjikan kontribusi yang lebih besar dimasa yang akan datang.

fek negara/wilayah yang bercorak agrikultur akan mempengaruhi peforma negara/wilayah industri (Yanagawa, 1996). Kondisi tersebut mesti didukung oleh kontribusi yang besar serta pertumbuhan sektor industri yang cepat. Hal itu terjadi apabila bahan mentah produk pertanian, kehutanan dan perikanan dapat diolah di wilayah tersebut menjadi produk sehingga memberikan nilai tambah ekonpomi di wilayah tersebut.

Sektor administrasi pemerintahan, pertahanan dan jaminan sosial wajib juga merupakan sektor yang unggul dengan karakter yang sama pada sektor yang du gambarkan sebelumnya. Sebagai salah satu provinsi termuda maka sektor pemerintahan juga mengalami peningkatan.

Hal yang menarik juga adalah sektor yang paling berkontribusi besar terhadap PDRB Provinsi Kalimantan Utara yaitu Sektor pertambangan dan galian, dengan nilai sebesar 23,6 triliun rupiah dan berkontribusi sebesar 27.51\% terhadap PDRB. Di samping berkontribusi besar tetapi pertumbuhannya cenderung bertahan di atas rata-rata pertumbuhan sektor pertambangan dan galian secara nasional. Demikian halnya pada sektor konstruksi. Ini menandakan bahwa pembangunan infrastruktur yang pertumbuhannya lebih cepat di atas rata-rata pertumbuhan sektor kostruksi nasional.

Sektor yang berada pada kuadran kedua adalah sektor yang maju di provinsi Kalimantan Utara namun pertumbuhannya cenderung tertekan. Pada peta sektor ekonomi di atas menunjukkan bahwa sektor Transportasi dan Pergudangan masih tumbuh lamban di banding sektor yang sama di tingkat nasional. Wilayah provinsi Kalimantan Utara masih membutuhkan prasarana interkonektivitas antar wilayah yang lebih baik. Sebagian besar wilayah masih dihubungkan dengan sarana dan prasarana transportasi air.

Pada kuadran ke tiga yang terdiri atas Sektor Pengadaan Listrik dan Gas, Sektor Perdagangan Besar dan Eceran; Reparasi Mobil dan Sepeda Motor, sektor Penyediaan Akomodasi dan Makan Minum, Sektor Real Estate; Sektor Jasa Pendidikan; Sektor Jasa Kesehatan dan Kegiatan Sosial, Sektor Jasa Lainnya merupakan sektor yang potensial di masa yang akan datang. Sektor-sektor ini berkembang pesat meskipun saat ini masih memiliki kontribusi yang kecil terhadap PDRB Provinsi Kalimantan Utara.

Berdasarkan realita pada kuadran ke empat dapat dilihat bahwa sektor Industri Pengolahan; sektor Pengadaan Air, Pengelolaan Sampah, Limbah dan Daur Ulang; sektor Informasi dan Komunikasi; sektor Jasa Keuangan; sektor Jasa Perusahaan merupakan sektor yang relatif tertinggal di provinsi Kalimantan Utara. Mestinya sektor industri berkontribusi besar dan juga 
tumbuh dengan cepat di daerah yang potensial pada sektor pertanian, kehutanan dan perikanan. Hal tersebut menandakan bahwa produk yang sifatnya raw material kebanyakan di kirim keluar wilayah Provinsi Kalimantan Utara dan di proses menjadi produk jadi di wilayah lain. Hal lain bahwa minat masyarakat dalam hal kewirusahaan khususnya sektor industri pengolahan produk masih belum begitu besar.

Sektor yang sifatnya jasa masih berkontribusi kecil terhadap perekonomian. Sektor tersebut adalah sektor Jasa Pendidikan; sektor Jasa Kesehatan dan Kegiatan Sosial; sektor Jasa Lainnya. Sementara itu, sektor Jasa Keuangan; dan sektor Jasa Perusahaan masih relatif tertinggal. Pembangunan ekonomi secara khusus berhubungan dengan perubahan struktural agrukultur dan manufaktur menjadi pelayanan/ jasa (Heger \& Neumayer, 2019). Pemerintah mesti memberikan dukungan terhadap peningkatan kontribusi sektor jasa terhadap perekonomian sebagai pendukung dalam proses pembangunan ekonomi yang bersifat sektoral.

Peta sektor ekonomi di atas memperlihatkan gambaran terhadap pola ekonomi di Provinsi Kalimantan Utara. Dimana menjadi kekuatan kita dan dimana yang menjadi kelemahan kita. Perhatian pada kinerja sektorsektor ekonomi mesti lebih ditingkatkan dengan indikator gambaran perekonomian ini.

\section{KESIMPULAN DAN SARAN}

\section{Kesimpulan}

Berdasarkan hasil analisis, dapat disimpulkan bahwa Pemetaan kategori sektor ekonomi di Kalimantan Utara terdiri atas

1. kuadran pertama yang merupakan sektor yang maju dan tumbuh dengan cepat terdiri atas: Pertanian, Kehutanan, dan Perikanan; Pertambangan dan Penggalian; Konstruksi; Administrasi Pemerintahan, Pertahanan dan Jaminan Sosial Wajib,

2. kuadran kedua yang merupakan sektor yang berkembang cepat terdiri atas: Transportasi dan Pergudangan,

3. Kuadran ketiga yang merupakan sektor yang maju tapi tertekan terdiri atas : Pengadaan Listrik dan Gas; Perdagangan Besar dan Eceran; Reparasi Mobil dan Sepeda Motor; Penyediaan Akomodasi dan Makan Minum; Real Estate; Jasa Pendidikan; Jasa Kesehatan dan Kegiatan Sosial; Jasa Lainnya,

4. Kuadran keempat yang merupakan sektor yang relatif tertinggal terdiri atas: Industri Pengolahan; Pengadaan Air, Pengelolaan Sampah, Limbah dan Daur Ulang; Informasi dan Komunikasi; Jasa Keuangan; Jasa Perusahaan.

\section{Saran}

Adapun saran yang dapat kami usulkan dari penelitian ini adalah :

1. Pemerintah menjadikan dan pihak terkait menjadikan peta sektor ekonomi ini sebagai 
indikator arah pembangunan ekonomi sektoral di provinsi kalimantan Utara

2. Pemerintah lebih menaruh perhatian pada sektor yang tertinggal dan sektor potensial sehingga bisa lebih berkontribusi pada perekonomian Provinsi Kalimantan Utara.

\section{DAFTAR PUSTAKA}

Arsyad, L. (2005). Pengantar Perencanaan dan Pembangunan Ekonomi daerah (Edisi 2). Yogyakarta: Badan Penerbitan Fakultas Ekonomi (BPPE).

Basuki, M., \& Nugroho Mujiraharjo, F. (2017). Analisis Sektor Unggulan Kabupaten Sleman dengan Metode Shift Share dan Location Quotient. Jurnal Sains, Teknologi Dan Industri, 15(1), 52-60. https://doi.org/10.4103/2276-70 96.188531

BPS Provinsi Kalimantan Utara. (2019). PDRB Provinsi Kalimantan Utara tahun 2020. $B P S$.

Heger, M. P., \& Neumayer, E. (2019). The impact of the Indian Ocean tsunami on Aceh's long-term economic growth. Journal of Development Economics, 141(June), 102365. https://doi.org/10.1016/j.jdevec o.2019.06.008

Hendayana, R. (2016). Aplikasi Metode Location Qoutient (LQ) dalam Penentuan Komoditas Unggulan Nasional. (March).

Kamaruddin, C. A., \& Alam, S. (2018). Analisis Potensi Sektor Unggulan dan Pemetaan
Kemiskinan Masyarakat di Wilayah Maminasata Sulawesi Selatan. Jurnal Administrare: Jurnal Pemikiran Ilmiah Dan Pendidikan Administrasi Perkantoran, 5(2), 85-98. Retrieved from http://ojs.unm.ac.id/index.php/a dministrare/index

Kurniawan, B. (2016). Analisis Sektor Ekonomi Unggulan Kabupaten Kerinci Provinsi Jambi. Jurnal Ekonomi Islam El-JIZYA.

https://doi.org/https://doi.org/10 .24090/ej.v4i1.2016.pp1-26

Ragiliawan, Z., Saputri, O. D., \& Nuraeni, Y. (2018). Aplikasi Location Quotient dan Tipologi Klassen untuk Memghitung Produktivitas, Laju Produktivitas dan Elastisitas Tenaga Kerja pada Sektor basis. (1999), 387-398.

Tamura, R., Dwyer, J., Devereux, J., \& Baier, S. (2019). Economic growth in the long run. Journal of Development Economics, 137(October 2018), 1-35. https://doi.org/10.1016/j.jdevec o.2018.10.010

Todaro, M., \& Smith, S. C. (2011). Economic Development (11th ed.). In Economic Development (11th ed.). Retrieved from https://b-

ok.cc/book/1183021/c59931

Way, E., Engka, D. S. M., \& Siwu, H. F. D. (2019). Analisis Sektor Ekonomi Unggulan di Kabupaten Sorong Selatan. Jurnal Berkala Ilmiah Efisiensi, 19(2), 35-48.

Yanagawa, N. (1996). Economic development in a world with many countries. Journal of 
Development Economics, 49(2), 271-288. https://doi.org/10.1016/0304-

3878(95)00062-3

\section{LAMPIRAN}

\section{PDRB Provinsi Kalimantan Utara Berdasarkan Lapangan Usaha Atas Dasar} Harga Berlaku

\begin{tabular}{|c|c|c|c|c|c|c|}
\hline \multirow[t]{2}{*}{ Kategori/Lapangan Usaha } & \multicolumn{6}{|c|}{ [Seri 2010] PDRB Atas Dasar Harga Berlaku Menurut Lapangan Usaha (Juta Rupiah) } \\
\hline & 2014 & 2015 & 2016 & 2017 & 2018 & 2019 \\
\hline $\begin{array}{l}\text { A. Pertanian, Kehutanan, dan } \\
\text { Perikanan }\end{array}$ & $10,120,512.90$ & $10,599,110.10$ & $11,568,458.47$ & $12,548,896.09$ & $13,806,577.83$ & $15,473,520.10$ \\
\hline $\begin{array}{l}\text { B. Pertambangan dan } \\
\text { Penggalian }\end{array}$ & $19,000,559.29$ & $17,403,029.72$ & $16,403,463.09$ & $21,051,543.67$ & $23,676,470.16$ & $26,259,903.00$ \\
\hline C. Industri Pengolahan & $5,626,185.65$ & $6,158,481.56$ & $6,708,025.68$ & $7,675,890.68$ & $8,116,669.54$ & $8,961,292.20$ \\
\hline D. Pengadaan Listrik dan Gas & $19,794.51$ & $26,422.19$ & $33,393.33$ & $41,156.71$ & $46,641.32$ & $50,798.70$ \\
\hline $\begin{array}{l}\text { E. Pengadaan Air, Pengelolaan } \\
\text { Sampah, Limbah dan Daur } \\
\text { Ulang }\end{array}$ & $35,871.91$ & $37,954.65$ & $41,323.44$ & $48,245.79$ & $53,454.08$ & $56,738.90$ \\
\hline F. Konstruksi & $6,895,409.83$ & $7,365,030.69$ & $8,481,885.92$ & $9,575,488.04$ & $11,106,598.83$ & $13,389,502.60$ \\
\hline $\begin{array}{l}\text { G. Perdagangan Besar dan } \\
\text { Eceran; Reparasi Mobil dan } \\
\text { Sepeda Motor }\end{array}$ & $5,889,425.25$ & $6,646,903.72$ & $7,634,116.45$ & $8,733,166.44$ & $10,039,428.50$ & $11,698,244.60$ \\
\hline $\begin{array}{l}\text { H. Transportasi dan } \\
\text { Pergudangan }\end{array}$ & $3,409,047.91$ & $4,019,913.72$ & $4,525,411.98$ & $5,374,661.11$ & $6,111,671.87$ & $6,871,591.30$ \\
\hline $\begin{array}{l}\text { I. Penyediaan Akomodasi dan } \\
\text { Makan Minum }\end{array}$ & $788,776.97$ & $898,726.62$ & $1,024,530.53$ & $1,208,056.36$ & $1,406,261.08$ & $1,574,480.60$ \\
\hline J. Informasi dan Komunikasi & $1,206,241.72$ & $1,378,112.73$ & $1,520,545.88$ & $1,764,486.23$ & $1,992,386.41$ & $2,262,828.70$ \\
\hline K. Jasa Keuangan & $653,095.65$ & $733,962.32$ & $819,202.27$ & $888,321.94$ & $979,974.53$ & $1,065,036.30$ \\
\hline L. Real Estate & $486,741.66$ & $532,939.37$ & $554,758.71$ & $604,822.22$ & $669,233.87$ & $746,027.40$ \\
\hline M,N. Jasa Perusahaan & $171,852.00$ & $175,771.13$ & $174,673.85$ & $189,242.01$ & $201,951.26$ & $213,950.30$ \\
\hline $\begin{array}{l}\text { O. Administrasi Pemerintahan, } \\
\text { Pertahanan dan Jaminan Sosial } \\
\text { Wajib }\end{array}$ & $2,888,081.68$ & $3,287,861.73$ & $3,671,738.45$ & $4,016,666.79$ & $4,337,890.16$ & $4,828,881.50$ \\
\hline P. Jasa Pendidikan & $1,258,396.36$ & $1,492,869.90$ & $1,713,014.69$ & $1,909,417.44$ & $2,091,996.76$ & $2,380,293.30$ \\
\hline $\begin{array}{l}\text { Q. Jasa Kesehatan dan } \\
\text { Kegiatan Sosial }\end{array}$ & $456,645.79$ & $601,966.79$ & $722,356.01$ & $790,372.94$ & $862,604.36$ & $988,706.70$ \\
\hline R,S,T,U. Jasa Lainnya & $277,363.74$ & $363,335.37$ & $444,914.51$ & $507,832.58$ & $559,076.22$ & $636,608.90$ \\
\hline $\begin{array}{l}\text { PRODUK DOMESTIK } \\
\text { REGIONAL BRUTO }\end{array}$ & $59,184,002.82$ & $61,722,392.31$ & $66,041,813.26$ & $76,928,267.04$ & $86,058,886.78$ & $97,458,405.10$ \\
\hline
\end{tabular}

Sumber : Badan Pusat Statistik (2020)

PDRB Provinsi Kalimantan Utara Berdasarkan Lapangan Usaha Atas Dasar

\section{Harga Konstan}

\begin{tabular}{|c|c|c|c|c|c|c|}
\hline \multirow[t]{2}{*}{ Kategori/Lapangan Usaha } & \multicolumn{6}{|c|}{ [Seri 2010] PDRB Atas Dasar Harga Konstan Menurut Lapangan Usaha (Juta Rupiah) } \\
\hline & 2014 & 2015 & 2016 & 2017 & 2018 & 2019 \\
\hline $\begin{array}{l}\text { A. Pertanian, Kehutanan, dan } \\
\text { Perikanan }\end{array}$ & $8,021,340.21$ & $8,574,016.31$ & $9,021,730.70$ & $9,420,028.27$ & $9,972,148.01$ & $10,560,477.80$ \\
\hline $\begin{array}{l}\text { B. Pertambangan dan } \\
\text { Penggalian }\end{array}$ & $15,345,733.71$ & $14,941,856.66$ & $14,415,640.76$ & $15,443,864.43$ & $16,156,384.17$ & $16,900,274.10$ \\
\hline C. Industri Pengolahan & $4,459,054.16$ & $4,732,387.75$ & $5,029,555.52$ & $5,308,101.98$ & $5,399,517.65$ & $5,660,572.70$ \\
\hline D. Pengadaan Listrik dan Gas & $22,594.63$ & $28,847.01$ & $31,172.04$ & $33,912.95$ & $37,701.90$ & $39,765.30$ \\
\hline
\end{tabular}




\begin{tabular}{|c|c|c|c|c|c|c|}
\hline $\begin{array}{l}\text { E. Pengadaan Air, Pengelolaan } \\
\text { Sampah, Limbah dan Daur } \\
\text { Ulang }\end{array}$ & $31,727.32$ & $32,486.69$ & $34,500.33$ & $37,005.06$ & $39,694.38$ & $40,828.30$ \\
\hline F. Konstruksi & $5,507,373.46$ & $5,709,650.32$ & $6,190,778.92$ & $6,570,561.91$ & $7,077,721.97$ & $7,928,456.70$ \\
\hline $\begin{array}{l}\text { G. Perdagangan Besar dan } \\
\text { Eceran; Reparasi Mobil dan } \\
\text { Sepeda Motor }\end{array}$ & $4,815,744.77$ & $4,956,085.97$ & $5,290,697.56$ & $5,736,806.25$ & $6,245,982.63$ & $6,855,366.70$ \\
\hline $\begin{array}{l}\text { H. Transportasi dan } \\
\text { Pergudangan }\end{array}$ & $2,694,262.82$ & $2,921,587.77$ & $3,091,050.67$ & $3,425,858.32$ & $3,724,509.08$ & $3,985,329.40$ \\
\hline & $572,312.05$ & $611,176.55$ & $660,672.91$ & $746,481.67$ & $835,788.90$ & $902,081.20$ \\
\hline J. Informasi dan Komunikasi & $1,149,747.08$ & $1,308,795.23$ & $1,412,686.97$ & $1,547,971.20$ & $1,688,717.25$ & $1,827,594.60$ \\
\hline K. Jasa Keuangan & $513,521.79$ & $554,558.88$ & $584,752.87$ & $608,296.35$ & $660,960.52$ & $696,597.70$ \\
\hline L. Real Estate & $461,330.83$ & $481,979.92$ & $488,910.37$ & $512,189.18$ & $544,293.39$ & $574,003.20$ \\
\hline M,N. Jasa Perusahaan & $143,028.20$ & $140,639.99$ & $134,478.93$ & $139,210.93$ & $144,499.49$ & $147,844.10$ \\
\hline $\begin{array}{l}\text { O. Administrasi Pemerintahan, } \\
\text { Pertahanan dan Jaminan Sosial } \\
\text { Wajib }\end{array}$ & $2,274,599.45$ & $2,415,145.39$ & $2,603,751.26$ & $2,780,612.90$ & $2,949,660.78$ & $3,147,414.50$ \\
\hline P. Jasa Pendidikan & $1,035,169.60$ & $1,140,884.06$ & $1,214,671.89$ & $1,306,139.76$ & $1,378,547.18$ & $1,512,181.70$ \\
\hline $\begin{array}{l}\text { Q. Jasa Kesehatan dan } \\
\text { Kegiatan Sosial }\end{array}$ & $422,384.02$ & $500,383.32$ & $564,175.96$ & $599,693.28$ & $631,151.21$ & $688,415.00$ \\
\hline R,S,T,U. Jasa Lainnya & $226,430.56$ & $265,263.22$ & $295,509.69$ & $317,772.82$ & $338,560.39$ & $367,376.90$ \\
\hline $\begin{array}{l}\text { PRODUK DOMESTIK } \\
\text { REGIONAL BRUTO }\end{array}$ & $47,696,354.66$ & $49,315,745.04$ & $51,064,737.35$ & $54,534,507.26$ & $57,825,838.90$ & $61,834,579.90$ \\
\hline
\end{tabular}

Sumber : Badan Pusat Statistik (2020)

\section{PDB Indonesia Berdasarkan Lapangan Usaha Atas Dasar Harga Berlaku}

\section{PDB Lapangan Usaha (Seri 2010) [Seri 2010] PDB Seri 2010 (Milyar Rupiah)} Atas Dasar Harga Berlaku

\begin{tabular}{|c|c|c|c|c|c|c|}
\hline & & & & & & \\
\hline & 2014 & 2015 & 2016 & 2017 & 2018 & 2019 \\
\hline $\begin{array}{l}\text { A. Pertanian, Kehutanan, dan } \\
\text { Perikanan }\end{array}$ & $1,409,655.70$ & $1,555,207.00$ & $1,671,597.80$ & $1,787,285.20$ & $1,900,348.50$ & $2,013,626.90$ \\
\hline B. Pertambangan dan Penggalian & $1,039,423.00$ & $881,694.10$ & $890,868.30$ & $1,029,554.60$ & $1,198,987.10$ & $1,149,913.50$ \\
\hline C. Industri Pengolahan & $2,227,584.00$ & $2,418,891.70$ & $2,545,203.60$ & $2,739,711.90$ & $2,947,299.20$ & $3,119,617.30$ \\
\hline D. Pengadaan Listrik dan Gas & $114,905.10$ & $129,833.70$ & $142,344.40$ & $162,339.90$ & $176,346.10$ & $185,115.30$ \\
\hline $\begin{array}{l}\text { E. Pengadaan Air, Pengelolaan } \\
\text { Sampah, Limbah dan Daur Ulang }\end{array}$ & $7,840.60$ & $8,546.30$ & $8,909.40$ & $9,439.60$ & $10,015.50$ & $10,736.30$ \\
\hline F. Konstruksi & $1,041,949.50$ & $1,177,084.10$ & $1,287,600.80$ & $1,410,513.60$ & $1,562,297.00$ & $1,701,741.20$ \\
\hline $\begin{array}{l}\text { G. Perdagangan Besar dan } \\
\text { Eceran; Reparasi Mobil dan } \\
\text { Sepeda Motor }\end{array}$ & $1,419,239.40$ & $1,532,876.70$ & $1,635,410.40$ & $1,768,896.10$ & $1,931,911.30$ & $2,060,772.60$ \\
\hline H. Transportasi dan Pergudangan & $466,968.90$ & $578,464.30$ & $644,993.90$ & $735,229.60$ & $797,281.10$ & $881,662.60$ \\
\hline $\begin{array}{l}\text { I. Penyediaan Akomodasi dan } \\
\text { Makan Minum }\end{array}$ & $321,062.10$ & $341,555.80$ & $363,055.50$ & $386,937.00$ & $412,523.10$ & $440,267.70$ \\
\hline J. Informasi dan Komunikasi & $369,457.30$ & $406,016.50$ & $449,188.70$ & $513,715.80$ & $559,054.60$ & $626,424.70$ \\
\hline K. Jasa Keuangan dan Asuransi & $408,438.80$ & $464,399.90$ & $520,206.80$ & $571,185.90$ & $616,252.80$ & $671,356.00$ \\
\hline L. Real Estate & $294,573.40$ & $327,601.40$ & $350,488.20$ & $382,474.10$ & $406,635.50$ & $439,367.10$ \\
\hline M,N. Jasa Perusahaan & $165,990.60$ & $190,267.90$ & $211,623.60$ & $238,217.00$ & $267,094.00$ & $304,285.50$ \\
\hline $\begin{array}{l}\text { O. Administrasi Pemerintahan, } \\
\text { Pertahanan dan Jaminan Sosial } \\
\text { Wajib }\end{array}$ & $404,629.60$ & $449,382.40$ & $476,490.90$ & $498,233.00$ & $541,741.20$ & $572,456.90$ \\
\hline P. Jasa Pendidikan & $341,818.40$ & $387,611.40$ & $417,344.80$ & $446,254.50$ & $482,134.10$ & $522,745.50$ \\
\hline $\begin{array}{l}\text { Q. Jasa Kesehatan dan Kegiatan } \\
\text { Sosial }\end{array}$ & $109,147.20$ & $123,191.50$ & $132,100.50$ & $144,621.90$ & $157,923.00$ & $174,801.70$ \\
\hline R,S,T,U. Jasa lainnya & $163,548.80$ & $190,581.00$ & $211,427.90$ & $239,259.00$ & $268,632.70$ & $308,839.60$ \\
\hline
\end{tabular}






Sumber : Badan Pusat Statistik (2020) 
